- FINANSE I PRAWO FINANSOWE.

- Journal of Finance and Financial Law

Wrzesień/September 2018 • vol. 3(19): 79-88

https://doi.org/10.18778/2391-6478.3.19.07

\title{
SEKTOR FIN-TECH - ZAGROŻENIE CZY SZANSA DLA BANKÓW?
}

Kamila Zelga

Uniwersytet Jana Kochanowskiego w Kielcach

\section{Streszczenie}

Postępująca globalizacja oraz dominacja nowoczesnych technologii powodują modyfikacje na wielu obecnych rynkach towarów oraz świadczonych usług. Banki podkreślają ideę równych szans dla wszystkich uczestników rynku, jednak powstaje pytanie czy stanowią wystarczająco elastyczne i konkurencyjne cenowo podmioty? Okazuje się bowiem, iż tradycyjna bankowość nie stanowi zagrożenia dla sektora Fin-Tech, nastawionego na współpracę w zakresie ożywienia sektora finansowego, dostosowującego swoje usługi do oczekiwań klientów. Wykazano, iż firmy Fin-Tech powinny poddać swoje firmy regulacjom sektora finansowego, co sprawi, iż wykreowane zostaną równe reguły gry wszystkich podmiotów oferujących podobne usługi oraz zapobiegnie arbitrażowi regulacyjnemu.

Słowa kluczowe: Fin-Tech, tradycyjne banki, regulacje, współpraca.

JEL Class: G2, G23, G28. 


\section{WPROWADZENIE}

W dobie przemian cyfrowych, zachodzących w coraz to większej ilości gałęzi światowych gospodarek, obecnie trudno jest wyobrazić sobie świat bez Internetu oraz wszelkich udogodnien mobilnych. Pędzący postęp technologiczny oraz globalizacja również powodują, iż takie same trendy i zjawiska widoczne są w branży usług finansowym, oferując całe spektrum świadczeń - od wymiany walut, nowoczesnych sposobów realizacji płatności, aż po udzielenie kredytów.

Biznes wykorzystujący innowacje oraz awangardowe technologie do konkurowania na rynku usług finansowych okrzyknięty został mianem Fin-Tech, a wraz z jego rozwojem tradycyjne instytucje finansowe dołączyły do grona zagrożonych utratą klientów na rzecz alternatywnych dostawców. Należy więc zadać pytanie, czy sektor Fin-Tech stanowi jedynie opozycję dla konwencjonalnych banków?

Celem niniejszego artykułu jest ukazanie zasadniczych różnic między sektorem Fin-Tech a tradycyjną bankowością oraz poddanie ocenie obszar Fin-Tech w kontekście konkurenta i potencjalnego partnera dla banków. Odwołano się także do postępującej innowacyjności polskich banków oraz regulacji sektora Fin-Tech, które niewątpliwie stanowią jeden z istotnych czynników ograniczających jego działalność.

Wywody oparto na analizie literatury przedmiotu, stron internetowych oraz dostępnych raportów dotyczących analizowanej problematyki.

\section{SEKTOR FIN-TECH A TRADYCYJNE BANKI}

Nie ulega wątpliwości, iż globalizacja oraz nowoczesne technologie przyczyniają się do silnych zmian na licznych rynkach dóbr i usług. Specyficzna sytuacja istnieje na rynkach finansowych, na których działają nie tylko instytucje poddane rygorystycznej regulacji, m.in. banki, ale także wiele parabanków.

Warto nadmienić, iż banki, mimo iż nie zawsze nadążają za postępującymi modyfikacjami, cieszą się zdecydowanie większym zaufaniem jako podmioty bezpieczne, podlegające regulacji oraz kontroli ze strony państwa.

Fin-Tech, czyli Financial Technology to innowacyjne usługi finansowe oparte na technologii informacyjnej. Funkcjonowanie firm Fin-Tech na rynku wywołuje pytania o równość reguł gry, ocenę konkurencji i współpracy, a także celowość poddania tych nowych konkurentów uregulowaniom banków, instytucji ubezpieczeniowych, firm inwestycyjnych, instytucji płatniczych czy instytucji pieniądza elektronicznego [Szpringer 2016: 56].

Kluczowe dla rozwoju jednolitego rynku w obszarze Fin-Tech jest budowanie pewności, iż nadmienione firmy mogą prowadzić transgraniczną działalność 
gospodarczą oraz kreować zaufanie wśród konsumentów w zakresie ochrony ich interesów $\mathrm{w}$ przypadku korzystania $\mathrm{z}$ usług na poziomie transgranicznym [Szpringer 2016: 56]. Równie istotne okazują się aspekty bezpieczeństwa informatycznego, ochrony tajemnicy handlowej czy zabezpieczenie prywatności, także w kontekście zezwolenia nowym podmiotom na dołączenie do instytucji infrastruktury rynku finansowego. Automatyczne kredytowanie w bankowości oraz mechaniczne platformy konsultingowe w sektorze ubezpieczeń świadczą o dużym potencjale rozwoju sztucznej inteligencji w ocenie ryzyka na rynku usług finansowych.

Powstają więc dylematy, co w dalszym horyzoncie czasowym zdominuje rynek detalicznych usług płatniczych: bankowe płatności, systemy kart płatniczych czy płatności internetowe? Czy przeważającą pozycję będą miały banki, czy też nowe firmy technologiczne o samodzielnym stanowisku lub działające w ramach współpracy z głównymi bankami? Czy w dalszej perspektywie banki w obecnej strukturze będą nadal funkcjonować, czy zostaną wyparte przez firmy Fin-Tech?

Sektor firm proponujących rozwiązania z zakresu Financial Technology (Fin-Tech) rozwija się bardzo prężnie - zarówno w kontekście wielkości inwestycji, jak i ilości spółek. Spośród ponad 140 przedsiębiorstw o wartości oszacowanej na ponad 1 miliard dolarów ponad 20 to spółki Fin-Tech [Zachariasz 2016].

Według raportu Accenture „The Future of Fin-Tech and Banking” globalna wartość inwestycji w spółki Fin-Tech wzrosła z 2 miliardów dolarów w roku 2010 do 12 miliardów dolarów w roku 2014 [EFMA, 2015].

Pomimo sukcesywnego tempa rozwoju oraz zysków, firmy działające w branży Fin-Tech są nadal zbyt małej skali, aby walczyć o prymat w świecie finansów. Jedna z największych firm z zakresu Fin-Tech, oferująca pożyczki online od 2007 roku, czyli od początku swojej działalności, integrowała w zobowiązaniach rzędu 13 miliardów dolarów. Dla porównania, w samych Stanach Zjednoczonych w roku 2014 firma VISA pośredniczyła w transakcjach kartami kredytowymi na łączną wartość 1,2 biliona dolarów, a zbiorczy kredyt konsumencki zaciągnięty na kartach kredytowych we wrześniu 2015 roku wynosił tam w sumie 3,5 biliona dolarów [Zachariasz 2016]. Olbrzymia dysproporcja w skali pokazuje, iż obecnie pozycja tradycyjnych banków jest dominująca, a ich funkcjonowanie nie jest zagrożone.

Jeśli więc Fin-Tech nie stanowi niebezpieczeństwa dla tradycyjnych instytucji finansowych, to czy przynajmniej determinuje ich transformacje? Wszystko wskazuje na to, iż taki wpływ istnieje i nadal się pogłębia.

Warto nadmienić, iż firmy z branży Fin-Tech oferują swoim klientom produkty dużo tańsze od tradycyjnej bankowości. Defekt konwencjonalnych kanałów sprzedaży, m.in. oddziałów czy brak konieczności zgodności z wytycznymi 
regulatora, powoduje znaczące obniżenie kosztów działalności i możliwość oferowania bardziej korzystnych cenowo produktów. Ponadto firmy z zakresu Fin-Tech coraz chętniej stosują innowacyjne sposoby oceny ryzyka, rozpoczynając od analizy behawioralnej swoich klientów opartej na mediach społecznościowych po algorytmy machine learning [Zachariasz 2016]. Stosowanie nowych modeli biznesowych pozwala na prowadzenie działalności para-bankowej bez obligatoryjności spełniania określonych wymogów stawianych bankom.

Globalne badania wskazują, iż kooperacja między bankami a spółkami Fin-Tech najczęściej dotyczy nowych metod płatności oraz marketingu cyfrowego, włączając innowacje w swoją oficjalną strategię działania. W roku 2009 tylko $37 \%$ banków traktowało innowacyjność jako jedną z metod osiągnięcia przewagi konkurencyjnej, natomiast 6 lat później to już 73\% banków [Accenture The Future of Fin-Tech, 2014].

Firmy Fin-Tech potrafią elastycznie, szybko i zwinnie przechwytywać wartość z nowych technologii i przekształcać je w nowe usługi, których życzą sobie ich klienci [Szpringer 2016: 57]. Przewiduje się, iż chociaż sektor Fin-Tech znajduje się jeszcze $w$ fazie rozwojowej, będzie on kształtował przyszłość rynku usług finansowych, jednocześnie przyciągając te osoby, które dotychczas nie były klientami tego typu usług lub korzystały z nich w niewielkim stopniu. Fin-Tech ma więc duży potencjał integracji finansowej oraz przeciwdziałania wykluczeniu finansowemu. Kluczową rolę we współpracy dostawców odgrywa kilka czynników, które wydają się decydować o powodzeniu Fin-Tech: niskie marże, brak konieczności inwestowania w drogie aktywa, innowacyjność, łatwa skalowalność i optymalizacja przestrzegania prawa [Teo i Kuo Chuen 2015: 15].

Firmy Fin-Tech pełnią także funkcję pośrednika między klientem a bankiem, które cenią nastawienie firm Fin-Tech na potrzeby i oczekiwania klienta, co sprawia, iż mogą oni produktywniej projektować usługi finansowe oferujące wartość dla klienta w zmiennym, wynikającym z rozwoju technologii łańcuchu wartości. Jak wynika z powyższego, należy podkreślić ukierunkowanie się banków bardziej na współpracę niż na konkurencję z sektorem Fin-Tech.

\section{INNOWACYJNOŚĆ POLSKICH BANKÓW}

Polacy znajdują się w zdecydowanej czołówce krajów otwartych na awangardowe technologie. Raport Fundacji Fin-Tech Poland „Fin-Tech w Polsce - bariery i szanse rozwoju" wskazuje, iż z bankowości elektronicznej korzysta obecnie 14 mln Polaków, natomiast z mobilnej $7 \mathrm{mln}$ [Widawski i Brakoniecki 2016: 18]. Kolejny czynnik przemawiający za przyjętą tezą stanowi zaawansowanie technologiczne polskich banków, wprowadzających innowacyjne rozwiązania, 
które są pozytywnie postrzegane przede wszystkim przez młode pokolenie użytkowników.

Polski Standard Płatności powstały w 2013 roku konstytuował rezultat porozumienia ponad podziałami sześciu banków: Alior Bank, PKO BP, BZ WBK, Banku Millenium, mBanku oraz IND Banku Śląskiego [Gnutek 2017: 14]. Nadmienić należy, iż obsługuje on system płatności BLIK, dostępnych za pośrednictwem aplikacji mobilnych powyższych banków oraz Orange Finanse i Getin Bank. Obecnie BLIK cieszy się dużym zainteresowaniem, gdyż z jego usług korzysta 3,5 milionami użytkowników, którzy realizują 2 miliony transakcji w ciągu miesiąca. W ten sposób komercyjne banki skutecznie oraz samodzielnie wdrożyły nowe rozwiązania technologiczne.

Podkreślić należy, iż tradycyjna bankowość nie lekceważy potencjału sektora Fin-Tech. Dla przykładu, mBank powołał projekt mAkcelerator, czyli fundusz, który w start-upy technologiczne ma zainwestować $50 \mathrm{mln}$ euro [Gnutek 2017: 14]. Własny program akceleracyjny posiada również PKO BP, gdzie wyłonione start-upy mogą skorzystać z merytorycznej wiedzy banku oraz wyjechać na Massachusetts Institute of Technology [Gnutek 2017: 14].

Z kolei Alior Bank już w 2015 roku powołał Innovation Lab - zespół mający na celu wdrożenie innowacji do oferty banku, efektem czego jest powstanie aplikacji mobilnej Trusted Advic [Gnutek 2017: 14]. Stworzona w kooperacji z IMP i Apple platforma umożliwiła doradcom codzienną obsługę klientów segmentu private banking, niezależnie od tego, gdzie aktualnie się znajdują.

\section{REGULACJE PRZESZKODA DLA FIN-TECH}

Działalność banków oraz organów nadzoru nad rynkiem finansowym nie została poddana jasnym i w pełni korzystnym regulacjom. Banki akcentują koncepcję równych reguł gry rynkowej dla wszystkich podmiotów, które świadczą podobne usługi i podejmują zbieżne ryzyko. Realizacji tego celu przyświeca pakiet regulacyjny CRD4/CRR - w sektorze bankowym, w ubezpieczeniach Solvency 2, natomiast na rynku kapitałowym - MiFID2/MiFIR, EMIR [Szpringer 2016: 58]. Unormowania te dotyczą w pewnym zakresie parabanków, obejmujących firmy Fin-Tech, w szczególności poza-bankowe prywatne systemy płatności [Kasiewicz i in. 2014: 140]. Organy nadzoru nad rynkiem finansowym koncentrują się wokół wpływu działalności Fin-Tech na stabilność finansową, z kolei podmioty ochrony danych osobowych rozważają bezpieczeństwo teleinformatyczne, w szczególności z perspektywy ochrony prywatności [Szpringer 2016: 58].

Obecnie, w dobie postępującej globalizacji oraz zmian technologicznych, konieczna jest zmiana nastawienia regulatorów rynku finansowego, którzy - obok kluczowej dla nadzoru kontroli nad stabilnością i bezpieczeństwem sys- 
temu finansowego promować powinni partnerstwo i współpracę między firmami Fin-Tech a bankami. Stymulowanie popytu konsumentów na cyfrowe usługi finansowe to nie tylko rozwój rynku, poprawa zaufania i tańsze usługi finansowe, lecz równocześnie przeciwdziałanie wykluczeniu cyfrowemu, finansowemu i społecznemu [Buckley i Malady 2015: 45].

Również raport Fin-Tech Poland „Fin-Tech w Polsce - bariery i szanse rozwoju" podnosi kwestie regulacji, które uniemożliwiają Fin-Techom racjonalną konkurencję z bankami. Na pytanie o działania, jakie należy podjąć, aby innowacje finansowe rozwijały się dynamicznie, aż $62,5 \%$ ankietowanych $\mathrm{z}$ branży Fin-Tech odpowiedziało: „Ograniczenie obciążeń regulacyjnych dla małych podmiotów" [Gnutek 2017: 15]. Sformułowanie to wybrało natomiast 10\% przedstawicieli banków. Z kolei na pytanie o największe bariery rozwoju sektora Fin-Tech w Polsce przedstawiciele tego obszaru najczęściej odpowiadali: „Zbyt wysokie wymogi regulacyjne i administracyjne" [Gnutek 2017: 15].

Pod tym względem szansą dla sektora Fin-Tech mogą być dyrektywy Parlamentu Europejskiego MiFID II oraz PSD 2. Zakładają one objęcie regulacjami cyfrowych walut $w$ zakresie przeciwdziałania konwersji pieniędzy i finansowania terroryzmu (AML) giełd wymiany kryptowalut. Uregulowania AML nakładają na niektóre podmioty finansowe obowiązki rejestracji transakcji, identyfikacji i weryfikacji klientów czy raportowania instytucjom państwowym określonych informacji.

Aktualnie używanie bitcoina w Unii Europejskiej jest legalne i nie podlega regulacjom. Co więcej, ostatnie orzeczenie Trybunału Sprawiedliwości zwolniło transakcje kryptowalutowe z podatku VAT w całej Unii Europejskiej [Szpringer 2016: 60]. Komisja zapowiedziała również objęcie tych podmiotów unormowaniem usług płatniczych.

Należy podkreślić, iż innowacyjny charakter bitcoina opiera się w głównej mierze na decentralizacji. W przypadku bitcoina nie istnieje centralny emitent - podobnie jak w odniesieniu do gotówki, a w przeciwieństwie do pieniądza bezgotówkowego przepływ płatności nie wymaga pośrednictwa zaufanej trzeciej strony, takiej jak bank [Szpringer 2016: 60]. Transakcje potwierdzane są za pośrednictwem szczególnego rodzaju porozumienia, osiąganego w drodze głosowania przez podmioty sieci bitcoin nazywanych minerami, przy czym wartość oddanej oceny zależna jest od mocy obliczeniowej dostarczonej przez danego minera na potrzeby przyzwolenia danej transakcji [Szpringer 2016: 60]. Odmienne właściwości bitcoina, takie jak względna anonimowość porozumienia czy też niskie koszty transakcyjne, są pochodnymi rozproszenia cyfrowej waluty. To właśnie decentralizacja bitcoina, scalona z cyfrową naturą tej jednostki pieniężnej, powoduje przeważające problemy prawne i podatkowe związane z jego kreacją i obrotem. 


\section{FIN-TECH - WSPÓŁPRACA CZY KONKURENCJA NA RYNKU USŁUG FINANSOWYCH?}

Konwergencja urządzeń oraz ich cyfryzacja, zacieranie się granic między tradycyjnymi mediami, telekomunikacją a Internetem, rozwój usług mobilnych czy też serwisów społecznościowych stawiają nowe, coraz to bardziej wymagające wyzwania przed regulacją sektorową, prawem własności intelektualnej, mediów elektronicznych oraz konkurencji [Szpringer 2016: 60].

Warto nadmienić, iż niezmiennie istotny problem $\mathrm{w}$ zakresie działalności Fin-Tech stanowi problematyka sztucznej inteligencji, automatycznych systemów eksperckich, wirtualnej edukacji, a także „Internetu rzeczy”, w szczególności odpowiedzialności jednostek ludzkich za automatyczne działania maszyn i urządzeń. „Internet rzeczy” kreuje nowe wyzwania dla regulacji, gdyż przedmioty fizyczne $w$ ramach tej specyfiki nabierają znamion typowych dla innych działów prawa, wykraczających poza prawo rzeczowe [Szpringer 2016: 60].

Rozwój rynku powinien zostać rzetelnie analizowany przez firmy Fin-Tech, gdyż z wyszukiwarkami czy serwisami społecznościowymi coraz częściej kojarzone są usługi finansowe, np. płatności internetowe i mobilne, pożyczki społecznościowe, crowdfunding czy usługi inwestycyjne [Szpringer 2016: 60]. Przedsiębiorstwa mogą antycypować zmiany w turbulentnym otoczeniu za pomocą: wzmocnienia własnej pozycji rynkowej w drodze fuzji i przejęć w zakresie kooperacji z konkurentami, tworzenia układów sieciowych i platform internetowych oraz uwzględniania portfela kilku modeli biznesowych, które dają większe poczucie bezpieczeństwa $\mathrm{w}$ zmiennych warunkach rynkowych [Pakulska i Poniatowska-Jaksch 2015: 8].

Banki zobligowane są do dostosowania się do zmieniających się warunków oraz podjęcia współpracy z firmami Fin-Tech. W tej relacji banki reprezentują konserwatywny świat finansów, z kolei firmy technologiczne mają pomysły, jak zaspokoić oczekiwania wchodzącej na rynek grupy nowych klientów spodziewających się wygodnych rozwiązań technologicznych [Twaróg 2016].

Integracja bankowości z telekomunikacją określa nowe modele biznesowe, zmierzające do przesunięć w łańcuchu wartości, by powstała nowa jakość pożądana przez konsumentów. Odnosi się to zatem do bankowości nowej generacji, gdyż banki coraz chętniej decydują się na współpracę z operatorami komórkowymi, tworząc platformy dla firm oraz oferując usługi księgowe, windykacyjne czy marketingowe. Mają w tej mierze do wyboru kilka strategii, m.in. platformę P2P, czyli sposób na detaliczne pośrednictwo finansowe i zagospodarowanie nowych nisz rynkowych, co oznacza obniżkę kosztów transakcyjnych. O ile platformy pożyczkowe P2P w Polsce są jeszcze niezbyt liczne, w Wielkiej Brytanii działają od dawna i odnoszą sukcesy. 
Orientacja światowego sektora bankowego koncentruje się coraz bardziej na regulacjach technologicznych w konsekwencji rosnącego zagrożenia ze strony agresywnych graczy spoza sektora bankowego. W praktyce jednak każdy wymiar działalności banków ma swój ekwiwalent w metodach proponowanych przez firmy technologiczno-finansowe, które mogą modyfikować rynek usług finansowych. Powstaje pytanie, czy może spełnić się przewidywanie Billa Gatesa sprzed lat, który twierdzil, iż bankowość będzie potrzebna, ale banki niekoniecznie [Pakulska i Poniatowska-Jaksch 2015: 8]?

Ukazana wizja rynku finansowego staje się coraz bardziej realna [Pakulska i Poniatowska-Jaksch 2015: 8]. Najbardziej innowacyjne banki, do których należy mBank i Alior - jako pierwsze zauważyły, iż należy wejść w strategiczny układ z telekomem, co może zapewnić dogodne warunki rozwoju biznesu oraz wysoką rentowność na długie lata.

W sytuacji, gdy dochodowość z jednego klienta w sektorze bankowym zaczyna spadać, możliwości cross-sellingu są ograniczone, koszt pozyskania klientów jest znaczny, a sieć placówek potrzebnych do pozyskiwania klientów kosztowna, wydaje się, iż alternatywa skorzystania z punktów sprzedaży telekomu i dostęp do bazy jego klientów stanowią atuty [Szpringer 2016: 63]. Podejmowane przez firmy technologiczne próby wkroczenia na rynek usług finansowych nie zawsze kończą się sukcesem, chociaż niektóre z nich rozwijają się sprzyjająco i wchodzą z czasem do obrotu giełdowego.

Zarówno sektor bankowy, jak i firmy pożyczkowe, stają przed wyzwaniem zmierzenia się z nowicjuszami pochodzącymi z branży Fin-Tech, czyli przedsiębiorstwami posługującymi się nowoczesnymi technologiami w oferowaniu usług finansowych, czego przykładem mogą być platformy umożliwiające finansowanie społecznościowe [Ciesielski 2016].

Firmy z sektora Fin-Tech mają przewagę nad bankami, ponieważ są małe, elastyczne i posiadają szerszy zakres informacji o kliencie. Za pośrednictwem dostępu do kapitału, banki mogą jednak wykorzystywać pomyślne rozwiązania oraz metody stosowane przez takie firmy i wdrażać je z sukcesem w swojej działalności. W swojej strategii rozwoju na najbliższe lata powinny jednak uwzględniać coraz częściej spotykane wyzwania, takie jak działalność w otoczeniu niskich stóp procentowych oraz bezwzględniejsze regulacje kapitałowe i płynnościowe.

Fin-Tech to z kolei szansa dla liderów rynku consumer finance czy dużych podmiotów na tym rynku (Polski sektor bankowy..., 2015].

Potencjał innowacji omawianych podmiotów stwarza ogromne możliwości ożywienia sektora finansowego oraz lepszego dostosowania go do oczekiwań klientów. Ich działalność nie wymaga zaangażowania dużej ilości kapitału, a sektor ten jest w stanie szybko zdobywać klientów i generować przychody. 


\section{PODSUMOWANIE}

Innowacje w sektorze finansowym, w których przodują małe, zwinne i elastyczne firmy Fin-Tech, coraz częściej egzekwują wśród znacznie większych podmiotów rewizje ich modeli biznesowych. W obliczu impulsywnego wzrostu liczby firm Fin-Tech wykorzystujących technologie do oferowania usług finansowych, obecni uczestnicy rynku odczuwają permanentną presję na innowacyjność, która trwale modyfikuje sektor finansowy. Od wielu lat banki i inne instytucje finansowe stosowały podobne i niezmienne w czasie modele działalności, które przynosiły im ogromne zyski. Okazuje się jednak, iż aktualne schematy nie są już tak skuteczne w porównaniu $\mathrm{z}$ udogodnieniami wprowadzanymi na rynek przez firmy technologiczne, które z powodzeniem zaczęły funkcjonować w sektorze finansowym.

Ukazana charakterystyka sektora Fin-Tech w porównaniu z tradycyjną bankowością oraz jej ocena w kontekście zagrożeń i szans na rynku usług finansowych dowodzi, iż banki obecnie nastawione są na współpracę z sektorem Fin-Tech, która zmieni ich nastawienie na potrzeby klientów. Na podstawie analizy, wykorzystanej do niniejszej pracy stwierdzono, iż rynek w ciągu najbliższego horyzontu czasowego ustabilizuje się, a banki nie utracą wiodącej pozycji oraz opracują nowatorskie modele biznesowe oparte na wspólnym łańcuchu wartości z firmami Fin-Tech.

\section{BIBLIOGRAFIA}

Buckley R.P., Malady L., 2015, Building consumer demand for digital financial services - the new regulatory frontier, „Journal of Financial Perspectives”, Vol. 3, No. 3.

Ciesielski M., 2016, „Bye, bye banks”. Banki nie będa nam potrzebne?, Forsal, http://forsal.pl/artykuly/919157,wizjabilla-gates-a-dotyczaca-bankow.html.

Gnutek M., 2017, Sektor Fin-Tech - realne zagrożenie czy potencjalny partner dla banków?, „Profit Journal”, nr 2.

Kasiewicz S., Kurkliński L., Szpringer W., 2014, Zasada proporcjonalności. Przełom w ocenie regulacji, WIB, Alterum, Warszawa.

Pakulska T., Poniatowska-Jaksch M., 2015, Przegrupowania przedsiębiorstw $w$ procesie internacjonalizacji, [w:] M. Poniatowska-Jaksch (red.), Nowe myślenie w zarzadzaniu strategicznym przedsiębiorstwem, Oficyna Wydawnicza SGH, Warszawa.

Polski sektor bankowy jest stabilny, lecz czeka go wiele wyzwań, 2015, PR News, http://prnews.pl/wiadomosci/polski-sektor-bankowy-jest-stabilny-lecz-czeka-go-wielewyzwan-6551512.html.

Szpringer W., 2016, Fin-Tech - nowe zjawisko na rynku ustug finansowych, „E-mentor”, nr 2.

Teo E., Kuo Chuen D., 2015, Emergence of FinTech and the LASIC principles, „Journal of Financial Perspectives", Vol. 3, No. 3. 
Twaróg E., 2016, Czy firmy fintechowe sq zagrożeniem dla branży bankowej?, http://www.bankier.pl/.

Widawski P., Brakoniecki M., 2016, Raport „FinTech w Polsce - bariery i szanse rozwoju, Fin-Tech Poland, Obserwatorium.BIZ, Centrum Prawa Nowych Technologii.

Zachariasz I., 2016, Fin-Tech-zagrożenie czy szansa dla sektora bankowego. Bliska perspektywa, http://igorzacharjasz.innpoland.pl/.

EFMA - Infosys Finacle Innovation Survey, 2015, https://www.efma.com/study/detail/21891.

Accenture - The Future of FinTech, 2014, https://www.accenture.com/us-en/insight-futurefintech-banking.

\title{
FIN-TECH SECTOR - A THREAT OR A CHANCE FOR BANKS?
}

\begin{abstract}
The ongoing globalization and dominance of modern technologies cause modifications on many current markets of goods and services. Banks emphasize the idea of equal opportunities for all market participants, but the question arises whether they are sufficiently flexible and competitively priced entities? It turns out that traditional banking is not a threat to the Fin-Tech sector, focused on cooperation in the recovery of the financial sector, adapting its services to customer expectations. It has been shown that Fin-Tech companies should submit their companies to financial sector regulations, which will result in creating equal rules of the game for all entities offering similar services and preventing regulatory arbitrage.
\end{abstract}

Keywords: Fin-Tech, traditional banks, regulations, cooperation. 